\title{
OBSERVATIONS ON CHYTRIDIACEOUS PARASITES OF PHANEROGAMS. XXVII. A FURTHER STUDY OF PHYSODERMA HYDROCOTYLIDIS VIEGAS AND TEIXEIRA ${ }^{1}$
}

\author{
Frederick K. Sparrow \\ Botanical Gardens and Department of Botany, University of Michigan, Ann Arbor 48109
}

\begin{abstract}
A B S T R A C T
A further study of Physoderma hydrocotylidis from California on its host Hydrocotyle ranunculoides gives further details on its structure and development. EM micrographs reveal that the notably thin wall of the resting spore consists of an outer, an intermediate, and an inner layer. The complete wall thickness from measurements of these EM preparations is only $0.5 \mu \mathrm{m}$, the thinnest of any known Physoderma resting spore. Such resting spores germinate readily in 2-5 $\mathrm{h}$ by the dehiscence of a broad cap and formation of a protruding endosporganium. Zoospores from the latter infect epidermal host cells and produce either the endobiotic, polycentric rhizoidal system with tenuous filaments, turbinate cells and eventually resting spores, or a hitherto unknown epibiotic, monocentric, rhizidiaceous sporangial stage. Zoospores from the latter may all bear colorless lipid globules or all faintly orange-colored ones.
\end{abstract}

IN an earlier publication (Sparrow, 1968) a brief account was given of the obligate parasitic fungus Physoderma hydrocotylidis, first described from Brazil by Viégas and Teixeira (1943). Notes on its distribution in the Eastern United States and California, its appearance on the host leaves and germination of its resting spores were included in this account. No clear picture of its method of infection, polycentric endobiotic system on which the resting spores were formed, and no information on the monocentric epibiotic stage were given. Primarily, these considerable gaps in information were the result of the failure to obtain seedlings of the host which could be used to follow the development of the fungus from zoospore to zoospore in both stages; mature host tissue was too opaque to be of value in this respect. Recent studies, however, on the nearly transparent underwater bud scales of the Hydrocotyle, have obviated these difficulties and these essential features of the parasite were followed with great clarity.

MATERIALS AND METHODS-Infected host material collected in California in 1967 and maintained in tanks at the University of Michigan Matthei Botanical Gardens was used in this study. Unopened leaf and floral buds together with a portion of the shoot just below the node bearing them were excised and placed in shallow dishes of charcoal water containing swimming R.S. (resting spore) zoospores of the fungus and left in daylight in damp chambers (petri dishes) at 22-26 C. These R.S. zoospores had been ob-

\footnotetext{
${ }^{1}$ Received for publication 14 December 1976; revision accepted 15 May 1977.
}

tained from resting spores of Physoderma teased out from infected, rotted blades and petioles of the host which had been lying in water. Such spores germinated readily in the dishes of charcoal water and provided an abundance of the zoospores aforementioned.

At intervals, starting with $12 \mathrm{~h}$ of exposure to R.S. zoospores, bud scales were excised and examined for stages of the fungus, particularly for the epibiotic stage earlier suspected of being absent.

This species of Physoderma is unique in my experience in the ease and speed with which its resting spores germinate. It will be recalled that it is the aggregation of these bodies, formed endophytically in the unhypertrophied but eventually killed local areas of host parenchyma, that produces the cinnamon brown to black pustules on petioles and leaves and occasionally on rhizomes of the host (Sparrow, 1968). These somewhat ellipsoidal to irregularly shaped resting spores, $15-25 \mu \mathrm{m} \times 12-16 \mu \mathrm{m}$, slightly flattened on one face, have two remarkable features. The first of these is an extremely thin, faintly brown wall, which, with a Filar micrometer eyepiece measured $0.8-0.9 \mu \mathrm{m}$ and from EM preparations was calculated as being even thinner $(0.5 \mu \mathrm{m})$. This is the thinnest known wall of a Physoderma resting spore.

EM preparations ${ }^{2}$ (Fig. 1) indicate that the resting spore wall consists of three regions: an outer, very electron-dense layer (the amber-colored wall), an intermediate layer that shows little electron density and an innermost layer in con-

${ }^{2}$ I am indebted to Prof. R. J. Lowry for this preparation and photograph. 


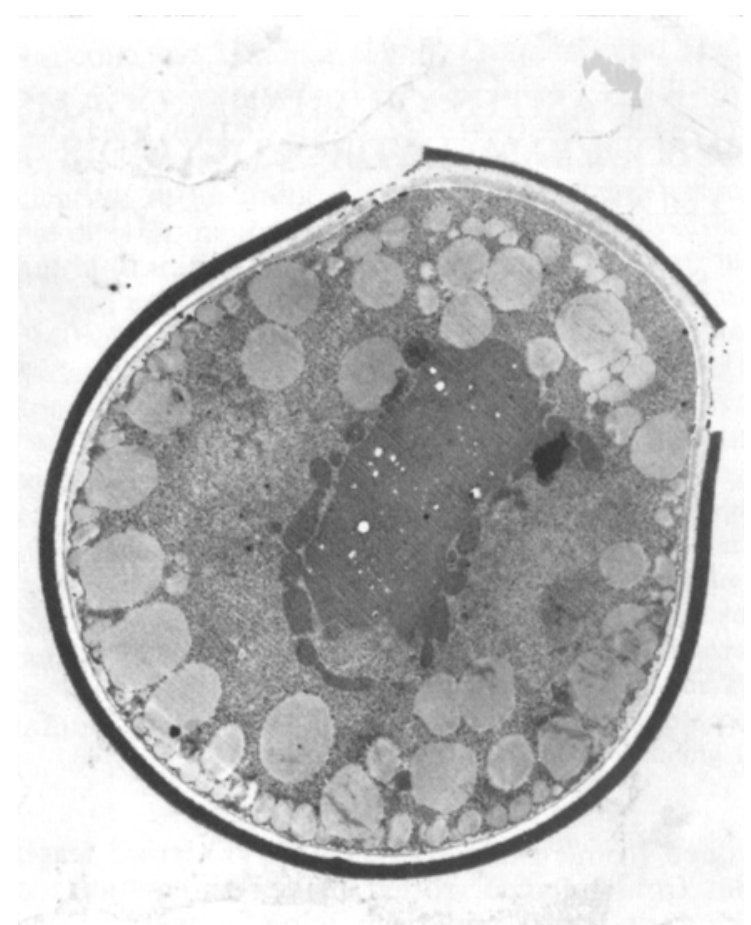

Fig. 1. EM photograph of a resting spore of Physoderma hydrocotylidis showing wall structure. The outermost, thickest wall (slightly brownish in living material) is a very electron dense layer. The dehisced, slightly thinner part composes the operculum. Beneath is an intermediate layer of little electron density, and an innermost layer, in contact with the plasma membrane, having a slightly greater density than the intermediate one. No interpretation of the contents will be given here. Prepared by Prof. R. J. Lowry. Standard glutaraldehyde-osmium fixation. $\times 2,500$.

tact with the plasma membrane, having a density slightly greater than the intermediate one. Several additional features may be noted. The lid or operculum which at germination will completely dehisce and be thrown back when the endosporangium starts to protrude, is seen to have a slightly thinner outer wall than the remainder of the spore body. Furthermore, the intermediate layer appears to become almost non-existent in the circumcissle zone of dehiscence, being defined peripherally by a very thin, electron-dense, somewhat discontinuous line. The thick remainder of this same intermediate layer becomes thinner toward the opposite end of the spore from the operculum.

A second feature of the resting spore is its speed of germination. Only $2-5 \mathrm{~h}$ are necessary under the conditions aforementioned for this process to be initiated, and in another hour, free swimming zoospores are seen. The germination process itself which involves the circumscissile dehiscence of a lid of wall material $10-15 \mu \mathrm{m}$ in diam from the flattened side of the spore and subsequent pushing out through the orifice of a finger-like endosporangium (Fig. 2) has been described before (Sparrow, 1968). Opportunity will be taken here, however, to correct an impression given of the thickness of the circumscissiley dehisced wall of the resting spore. This is shown as far too thick in Figures 4-12 of the 1968 paper, as the result of trying to show both edges of the cap. In Fig. 2 of the present paper the appearance is more accurately shown. As noted, EM photos show this operculum wall to be even thinner than that of the remainder of the spore (Fig. 1).

Resting spore zoospores which produce new infections are narrowly ovoid when moving (7 $\mu \mathrm{m} \times 5 \mu \mathrm{m})$, with an anterior arc of dense material (undoubtedly the nuclear cap), one or two dull granules, and a prominent, slightly basal refractive colorless globule (Fig. 2, 3). The posterior flagellum is $20-25 \mu \mathrm{m}$ long. During periods of amoeboid crawling, the internal structures change their position in the spore body but not their relative positions to one another (Fig. 3, right). Commonly, resting spores germinate within decaying, but as yet unopened, host cells and great numbers of R.S. zoospores are often trapped and mill around in such debris (Fig. 2). The planonts figured by Viégas and Teixiera (1943) which are doubtfully ascribed by them to their fungus cannot be these since they lack the prominent globules. In fact, these investigators say they did not successfully germinate the resting spores.

Epibiotic stage.-The epibiotic, monocentric stage which occurs on epidermal cells is clearly recognizable among encysted zoospores, primarily by their irregular shape (Fig. 4a, b, 5), $24 \mathrm{~h}$ after exposure of the host to R.S. zoospores. It was noted that such sporangia frequently developed in areas where the endobiotic system was also developing (Fig. 4c, d), but no physical connection between the two could be detected. Furthermore, there were very few R.S. zoospores undergoing epibiotic development compared with those forming the polycentric endobiotic system, a ratio on bud scales of roughly $1: 100$ or more. Early stages are not only irregularly elongate but also the presence of a slightly thickened portion of the zoospore cyst wall on the upper, central part of the young sporangium indicates that the latter will be of the "bilateral" type of development (Sparrow, 1975). At this stage, as viewed from above, no rhizoidal system anchoring the developing sporangium to the host can be detected ordinarily (Fig. 5). It is there, however, and if a side view can be obtained, it will show up clearly (Fig. 4b). Occasionally, as in certain other physodermas (e.g., $P$. gerhardti, Sparrow, Griffin, and Johns, 1961), dwarf sporangia (Fig. 11, 12) $12 \mu \mathrm{m} \times 7-8 \mu \mathrm{m}$ may mature and 
discharge their few spores. The great bulk of sporangia, however, steadily increase in size, and $48 \mathrm{~h}$ after exposure to R.S. zoospores, become ovoid, gibbose, colorless or, less often, faintly orange colored structures bearing the cyst apically, and a single broad basal discharge papilla (Fig. 6a), much like those of $P$. butomi (Buisgen, 1887; Sparrow, 1974). The rhizoidal system in such sporangia is apophysate (Fig. 9, 10) or non-apophysate (Fig. 7), and consists of a complex of somewhat short, stubby, branched rhizoids. Mature colorless sporangia are mostly 22-30 $\mu \mathrm{m} \times 10-26 \mu \mathrm{m}$, the pigmented ones, $22-$ $25 \mu \mathrm{m} \times 10-15 \mu \mathrm{m}$.

Zoospore formation is essentially like that described in detail for Physoderma gerhardti (Sparrow et al., 1961) on Agropyron repens and for P. lycopi (Sparrow, 1957) on Lycopus americanus, and need not be given in detail here. The zoospores escape upon dissolution of a prominent $5-6-\mu \mathrm{m}$ broad discharge papilla, usually oozing out in a coherent group which dissociates shortly into individual zoospores. Both colorless (Fig. 7a) and pigmented-globuled types (Fig. 7b) are at first spherical, $4-5 \mu \mathrm{m}$ in diam, the globule being $2.0-2.5 \mu \mathrm{m}$ in diam and the flagellum 15-20 $\mu \mathrm{m}$ long. During movement, the body, like that of the R.S. zoospore, becomes distinctly ovoid. The number of zoospores varies from two to about 20 , depending upon the size of the sporangium. Internal proliferation occurs (Fig. 8) but is not common, possibly because of low levels of nutrition prevailing in bud scale epidermal cells. The further fate of the epibiotic zoospores could not be followed because of the few available for transference to new tissue. It will be recalled that in $P$. gerhardti they could give rise either to new epibiotic sporangia, or to the endobiotic polycentric system.

Endobiotic stage-Coincident with epibiotic development, great numbers of R.S. zoospores had encysted on the surface of the epidermal cell, had penetrated the host, and had produced in the epidermal cell the rudiment of the primary turbinate cell. This body first appears inside the epidermal cell of the host as a globular structure at the tip of the penetration tube of the encysted R.S. zoospore (Fig. 4c). As it develops, rhizoidal outgrowths appear on the surface (Fig. 4d) which elongate, branch, and establish the thallus within the host. This primary turbinate cell, as it is called, frequently becomes compartmentalized by the formation of one or more membranes (walls?) (Fig. 13b; 15e), and from its body will be produced rhizoids which will extend through interior cells of the host. On these rhizoids will be formed secondary turbinate cells which often bear proximal whorls of short, unbranched haustorial processes as shown in Fig. 13 of a 48 -hourold thallus. The epibiotic cyst of the R.S. zoo- spore (Fig. 13a) has beneath it, endobiotically, a divided primary turbinate cell (Fig. 13b) which has given rise to a system of rhizoids upon which are secondary turbinate cells (Fig. 13c) bearing proximal tufts. The turbinate cells shown in Fig. $14 \mathrm{a}$ indicate the various types of compartmentalization which may occur and also indicate that all such cells do not bear tufts. Turbinate cells were ovate to pyriform and were $12-14 \times 4-8$ $\mu \mathrm{m}$. Some become 2-3-chambered (Fig. 14a); others remained 1-celled (Fig. 15b), and 12-15 $\mu \mathrm{m} \times 3-10 \mu \mathrm{m}$.

Resting spores were formed on some thalli within $48 \mathrm{~h}$ after exposure of host to R.S. zoospores, a rapidity of development we have not seen in other species of the genus. In this process, a short protrusion grows from a smoothwalled turbinate cell at the tip of which a constantly increasing globular mass forms-the rudiment of the resting spore (Fig. $15 \mathrm{a}, \mathrm{b}$ ). As in other species, delicate, usually branched outgrowths form (Fig. 14b; 15b) which usually, but not always (Fig. 15c), disappear by the time the rudiment begins to thicken its wall. Such outgrowths are frequently seen on the flat face of the maturing resting spore (Fig. 14b). Figure 15 also indicates that epibiotic stage formation occurs swiftly, too, since an empty sporangium (Fig. $15 \mathrm{~d}$ ) is found near a 48-hour-old endobiotic thallus bearing almost mature resting spores (Fig. $15 \mathrm{c})$.

Special features of the resting spores have already been given. It was noted that on bud scales the spores were distinctly smaller than those from leaf blade and petiole tissue (usually 14-15 $\times$ $12 \mu \mathrm{m}$ compared with $18-27 \times 12-16)$. No work has as yet been done on the host range of this species, but I have found that seedlings of the umbellifer Sium suave which harbours a Physoderma ( $P$. palustris) were not infected when exposed to R.S. zoospores of the Hydrocotyle parasite. Further information is being accumulated on its host range. ${ }^{3}$

A detailed amended description of the fungus is given forthwith.

\section{Physoderma hydrocotylidis Viégas and Teixeira emend.}

Bragantia 3:226. 1943. Fig. 1; Pl.4, Fig. a - d.

Epibiotic sporangia bilateral in development, ovoid, somewhat gibbose, with an apical hemispherical cyst and single, lateral to basal, 5-6 $\mu \mathrm{m}$ diam discharge papilla; rhizoidal system apophysate or nonapophysate, composed of short, stubby, branched rhizoids; contents colorless or faintly orange-colored; colorless sporangia 22

\footnotetext{
${ }^{3}$ Recent observations by G. B. and F. K. Sparrow indicate that $P$. hydrocotylidis will infect mature Sium in greenhouse tanks.
} 

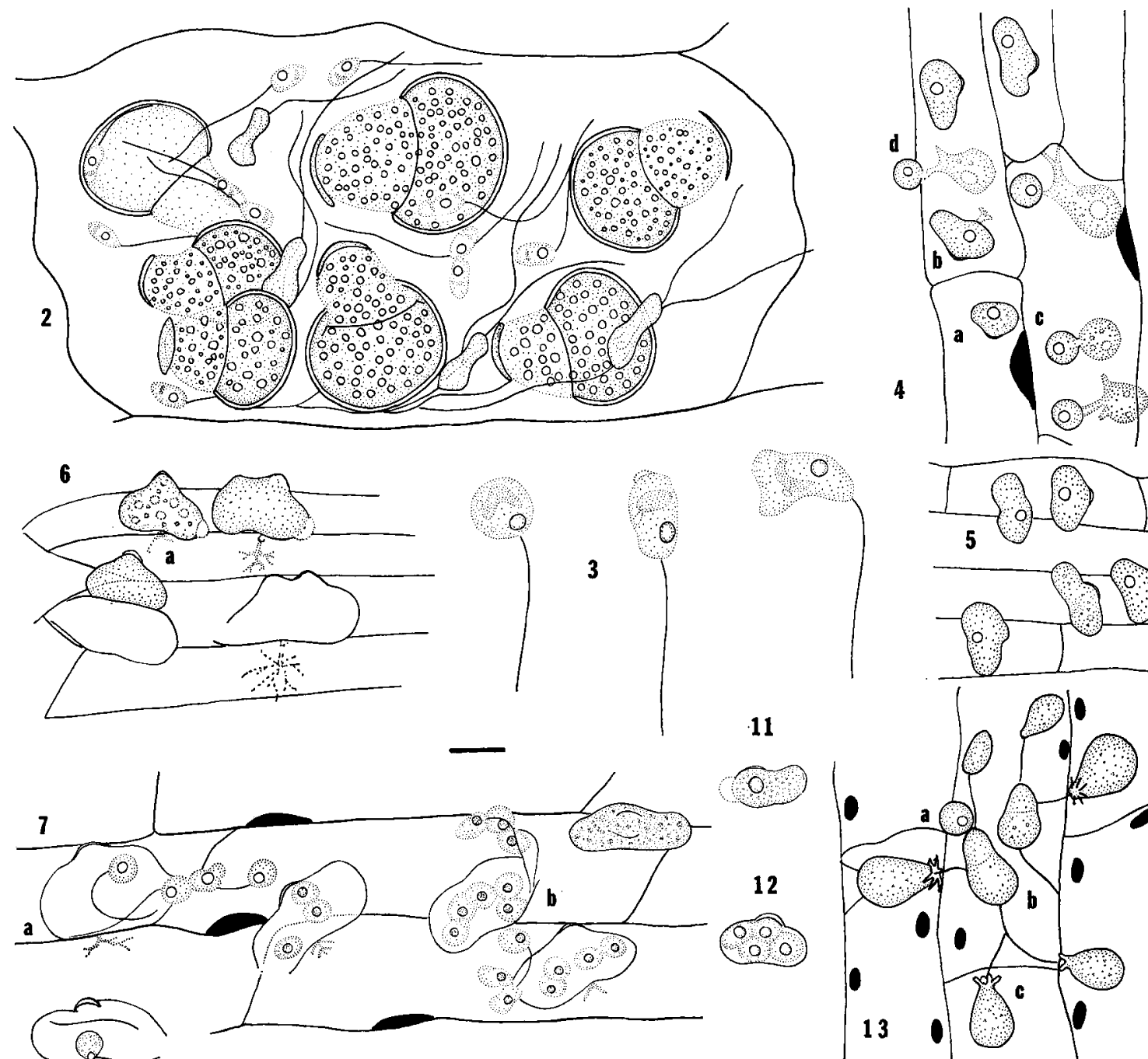

11
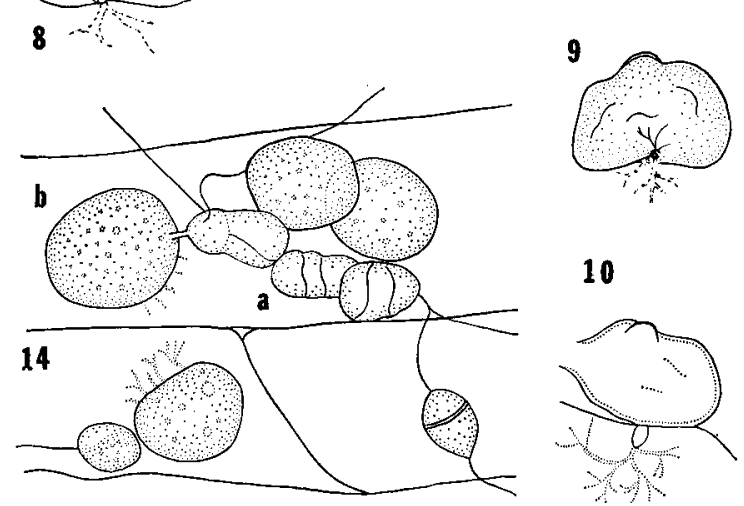

10
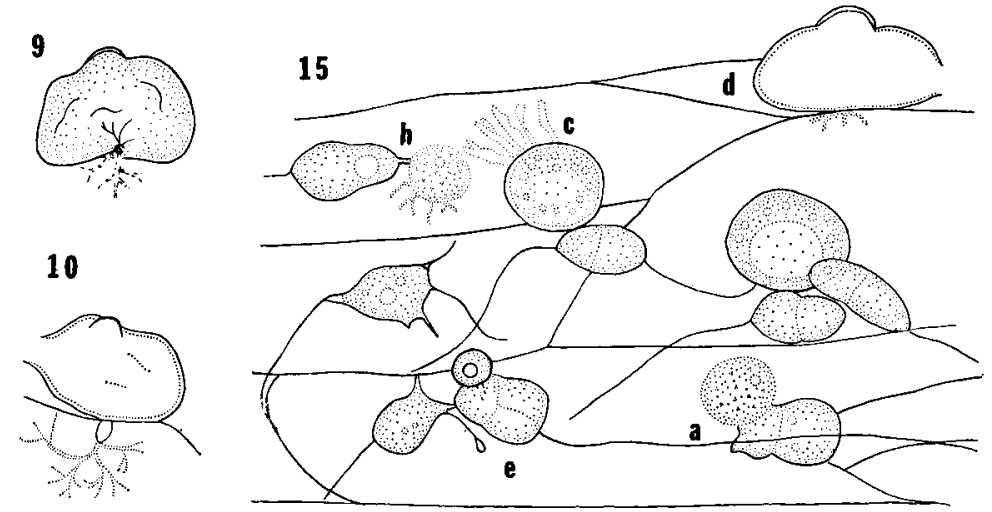

Fig. 2-15. Physoderma hydrocotylidis. 2. Decayed host cell with seven resting spores of Physoderma in various stages of germination. Numerous zoospores are swimming around in the cell. There are also remains of rhizoids and turbinate cells. 3. Three zoospores showing posterior flagellum, oil droplet, more opaque nuclear cap and one or two granules. The right hand one is undergoing amoeboid movement (freehand, greatly enlarged). 4. Bit of host bud scale tissue $24 \mathrm{~h}$ after exposure to R.S. zoospores; $4 \mathbf{a}, \mathbf{b}$. Encysted zoospores developing into epibiotic sporangia, $(b)$ has young rhizoids visible. Fig. 4c. Epibiotic cyst has produced a spherical endobiotic rudiment of primary turbinate cell. Fig. 4d. Endobiotic p.t.c. rudiment producing beginning of rhizoidal system. In host cell to 
$30 \mu \mathrm{m} \times 10-26 \mu \mathrm{m}$, pigmented ones 22-25 $\mu \mathrm{m} \times$ 10-15 $\mu \mathrm{m}$; dwarf sporangia $12 \times 7-8 \mu \mathrm{m}$; colorless and pigmented zoospores at first spherical and 4-5 $\mu \mathrm{m}$ in diam, becoming ovoid and $7.5 \mu \mathrm{m}$ $\times$ 4-5 $\mu \mathrm{m}$ with movement, with a prominent, nearly central globule $2.0-2.5 \mu \mathrm{m}$ in diam and 15-20 $\mu \mathrm{m}$ long posterior flagellum; internally proliferous. Endobiotic polycentric system composed of rhizoids, turbinate cells, and resting spores; rhizoids mostly unbranched, extending through many cells of the host, occasionally terminating in a cluster of delicate branches; turbinate cells occuring at intervals along the rhizoids, the primary one and most of the secondary ones broadly ovate to pyriform, $12-14 \mu \mathrm{m} \times 4$ $8 \mu \mathrm{m}$, and with one to several chambers ("cells"), a few pyriform, 12-15 $\mu \mathrm{m} \times 3-10 \mu \mathrm{m}$, onechambered and bearing a whorl of short, stubby outgrowths at the narrower, proximal end; resting spores arising at the tip of a short tubular outgrowth from the chamber of a secondary untufted turbinate cell, elipsoidal or occasionally irregular, slightly flattened on one face, when immature sometimes bearing tufts of short haustorial temporary outgrowths, $15-25 \mu \mathrm{m} \times 12-16 \mu \mathrm{m}$ (12-21 $\mu \mathrm{m} \times 10-20 \mu \mathrm{m}$ according to Viégas and Teixeira) with a $0.8-0.9 \mu \mathrm{m}$ thick outer wall, upon germination dehiscing a broad operculum 10$15 \mu \mathrm{m}$ in diam from the flattened face of the spore; an elongate, saccate, or finger-like endosporangium of variable size depending upon the size of the resting spore, gradually growing out of the orifice; zoospores at first spherical, ovoid to fusiform and $7 \mu \mathrm{m} \times 5 \mu \mathrm{m}$ when moving, with an anterior arc of dense material, one or two dull granules, a prominent slightly basal $2-2.5 \mu \mathrm{m}$ colorless globule, and 20-25 $\mu \mathrm{m}$ long flagellum, zoospores escaping through a pore formed at the tip of the endosporangium.

Parasitic on Hydrocotyle reniformus Spreng., Brazil, Viégas and Teixeira (1943); H. ranunculoides, United States, Sparrow (1968); Hydrocotyle sp. and $H$. umbellata; Diehl (in Sparrow, 1968), Bonar (in Sparrow, 1968).

\section{LITERATURE CITED}

BüsGeN, M. 1887. Beitrag zur Kenntnis der Cladochytrien. Cohn. Beitr. Biol. Pflanz. 4: 269-283. SPARROW, F. K. 1957. Observations on chytridiaceous parasites of phanerogams. VII. A Physoderma on Lycopus americanus. Amer. J. Bot. 44: 661-665.

- 1968. Physoderma hydrocotylidis and other interesting Phycomycetes from California. J. Elisha Mitchell Sci. Soc. 84: 62-68.

- 1974. Observations on chytridiaceous parasites of phanerogams. XX. Resting spore germination and epibiotic stage of Physoderma butomi Schroeter. Amer. J. Bot. 61: 203-208.

. 1975. Observations on chytridiaceous parasites of phanerogams. XXIV. The epibiotic stage of Physoderma. Can. J. Bot. 53: 1365-1370.

, J. E. GRIFFIN, AND R. M. JoHNs, 1961. Observations on chytridiaceous parasites of phanerogams. XI. A Physoderma on Agropyron repens. Amer. J. Bot. 48: 850-858.

Viégas, A. P., and A. H. TenxeIra. 1943. Alguna fungos do Brazil (Phycomycetes). Bragantia 3: 223-245.

$\leftarrow$

right, the p.t.c. rhizoid has branched. 5. Cluster of slightly more developed epibiotic sporangia on surface of epidermal cells. Here, the slightly thickened wall of the cyst is becoming more apparent. 6. Maturing and empty epibiotic sporangia showing rhizoidal system. At $(a)$ and the sporangium to the right, a basal discharge papilla appears. The gibbose shape of sporangia is well seen here. 7. Discharging sporangia and zoospores of colorless $(a)$, and pigmented $(b)$ types shown. Upper right body is immature pigmented sporangium. 8. Empty, non-apophysate sporangium showing internal proliferation. 9, 10. Empty apophysate sporangia. 11, 12. Dwarf epibiotic sporangia. 13. Forty-eight hour old endobiotic polycentric thallus showing epibiotic R.S. zoospore cyst at $(a)$; compartmentalized endobiotic p.t.c. at $(b)$, and secondary t.c. with proximal tuft at $(c)$. 14. Older endobiotic thalli showing several-celled t.c. at $(a)$, and to left a young resting spore with outgrowths; at $(b)$ and in cell below, young resting spores with delicate haustorial outgrowths. 15. Tissue showing endobiotic t.c. giving rise to resting spores $(a),(b)$; nearly mature resting spore with persistent outgrowths at $(c)$; empty epibiotic sporangium at $(d)$; at $(e)$ there is an epibiotic cyst of R.S. zoospore, beneath it the 3-segmented p.t.c. and a secondary t.c. The bar just beneath Fig. 3 (left) is $10 \mu \mathrm{m}$. 